- the second experiment was conducted on 2 groups of 12 pigs in each (castrated males and females) with two pens per treatment. In these two treatments, the pigs were fed either regular or hulless barley from 30 to $\mathrm{r}$ oo $\mathrm{kg}$ liveweight, in the same feeding conditions with regard to energy-protein balance and energy level, which was differenciated according to sex in order to obtain lean carcasses.

From the digestibility trial, apparent digestibility of energy (ADIi) and nitrogen (ADN), DE and MEn values, in kcal per kg dry matter (DM) were respectively :

- for a regular barley (Winter variety Astrix) containing 7.21 p. Ioo crude fibre in DM : 79.4; $76.8 ; 3432$ and 3309 .

- for a hulless barley (a hybrid variety from INRA) with 2.80 p. Ioo crude fibre in DM: 86.4 ; $81.2 ; 3757$ and 3612 .

From these results we could establish a simple mean for predicting the DH or MEn value of barley according to its crude fibre content, on the basis of I.5 point decrease of ADE for I p. IOO increase of crude fibre in DM versus I p. Ioo for ADN. Thus, the DE value decreased by $70-80$ kcal for I p. Ioo increase in the crude fibre level in the fresh material ( $87 \mathrm{p}$. IOO DM). The MEn value may be obtained from DE after multiplying by the coefficient 0.96 . Evaluating the nutritional value of barley on this basis is perfectly founded since the two types of cereals (regular and hulless) were similar in the growth trial, when considering average daily gain, energy efficiency and carcass characteristics and for the same levels of energy and protein.

\title{
Performances of Large White pigs subjected to individual or paired feeding : variations related to sex and castration
}

\author{
J. M. PEREZ and B. DESMOULIN \\ Station de Recherches sur l'ílevage des Porcs, I. N. R. A., C. N. R. Z., \\ 78350 Jouy in Josas
}

The feeding trials performed at the experimental station are most frequently made with animals placed in indiviclual pens, as the feed intake and nutritive utilization of the diets can only be accurately determined under these conditions. However, it is reproached about this method that it changes the feeding behaviour of the animals. Therefore, in pig testing stations, two animals of the same sex are generally placed together in the same pen.

The purpose of the present experiment was to examine if the level and homogeneity of the performances are modified according to the fecding method (individual or paired feeding) in $a d$ libitum fed and separately kept male and female pigs.

The trial was made on 72 Large White pigs (entire males, castrated males, females) between I 8 and roo $\mathrm{kg}$ live weight. During the whole growth period, the animals received a single diet containing 15.3 p. Ioo crude protein and $3050 \mathrm{kcal}$ digestible energy.

The results obtained lead to two series of conclusions :

r. Under our experimental conditions, fattening and carcass traits taken as a whole were comparable for the two feeding methods (indiviclual or paired) : daily mean gain : $688 \mathrm{~g} / \mathrm{d}$; feed conversion ratio : 3.43 ; back fat thickness : $29 \mathrm{~mm}$. However, differences werenoticed, depending on the sex of the animals: in hogs the number of animals per pen clid not affect the performance criteria, whereas in boars, individual housing tended to increase the feed intake level. $(2 .+$ versus $2.2 \mathrm{~kg} / \mathrm{clay}$ ) and to a less extent, this was also the case for lemales (2.38 versus $2.25 \mathrm{~kg} / \mathrm{day})$. 
Furthermore, feeding in individual pens led to reduction of the variability of body composition criteria (variation coefficients reduced by $20 \mathrm{p}$. Ioo on an average). Thus, this method allows to increase the accuracy of young males testings at the station, as well as that of the measurements made during the feeding trials, without reducing the feed intake level of the animals.

2. Body composition traits estimated in this trial by means of various methods (measurement of fat thickness, weight of cuts, estimation of specific gravity) confirm the low carcass quality of ad libitum fed Large White pigs (loin/backfat ratio varying from I.5 to 2.2). Moreover, the $36 \mathrm{p}$. roo reduction of the carcass quality and $15 \mathrm{p}$. Ioo increase of the feed intake (corresponding to $3^{8} \mathrm{~kg}$ feed per pig) in the castrated males as compared to the non castrated ones (males or females) emphasize once more the economic loss resulting from castration of pigs from this breed.

\title{
Measurement of zootechnic performances in pigs subjected to a pre-fattening period of variable length
}

\author{
J. P. BOUARD and M. LEUILLET \\ Institut technique des Céréales et des Fourrages, \\ 8. Avenue du Président Wilson, \\ 75116 Paris
}

The purpose of this trial was to compare two rearing techniques for bacon pigs :

- classical rearing in one only piggery with restricted feeding;

- two rearing phases : a growing period with ad libitum feeding (pre-fattening) and a finishing period with restricted feeding in another piggery. The length of the pre-fattening periods was 28,42 or 56 days.

In our experimental conditions, the best technique from both a zootechnic and economic point of view is that based on the association of severe restriction during the finishing period and a long lasting pre-fattening period ( $4^{2}$ or 56 days), i. e. till a mean weight of $65 \mathrm{~kg}$.

\section{Maize and barley flaking and popping}

\author{
I. - Processing \\ II. - Flaked Maize digestion in the growing Pig
}

L. P. BORGIDA

Laboratoire de Technologie des Aliments des Animaux, I. N. R. A., C. N. R. Z., 78350 Jouy en Josas

\section{I. - Processing}

Steam flaking $\left(\mathrm{I}^{\circ} \mathrm{O}^{\circ} \mathrm{C}, 45\right.$ or $\left.55 \mathrm{mn}\right)$ and grain popping in $280^{\circ} \mathrm{C}$ heated air during $5^{\circ}$ seconds increases long chain soluble carbohydrate formation and intensify $\alpha$-amylase in vitro action upon starch.

Annales de Zootechnie. -- 1975. 